\title{
Geographical Penetration, Composition, Unit Value Realisation, Exports Competitiveness and Market Diversification of Shrimp Exports from India
}

\author{
Naorem Dinesh Singh ${ }^{1 *}$, M. Krishnan ${ }^{2}$, Swadesh Prakash ${ }^{3}$, V.R. Kiresur ${ }^{4}$, \\ N. Sivaramane ${ }^{5}$ and S.K. Pandey ${ }^{6}$
}

\begin{abstract}
${ }^{1}$ Fisheries Economics Extension Statistics Division, ICAR-Central Institute of Fisheries Education, Mumbai, India
${ }^{2}$ Education Systems Management Division, ICAR-National Academy of Agricultural Research Management, Rajendra Nagar, Hyderabad, India

${ }^{3}$ Fisheries Economics Extension Statistics Division, ICAR-Central Institute of Fisheries Education, Mumbai, India

${ }^{4}$ Department of Agricultural Economics, University of Agricultural Sciences (D), Vijayapur Campus, Vijayapur, Karnataka, India ${ }^{5}$ Agribusiness Management Division, ICAR-National Academy of Agricultural Research Management, Rajendra Nagar, Hyderabad, India
\end{abstract}

${ }^{6}$ Fisheries Economics Extension Statistics Division, ICAR-Central Institute of Fisheries Education, Mumbai, India

*Corresponding author: naoremdinesh15@gmail.com

\begin{abstract}
In India, fisheries is an economic activity contributing $17.07 \%$ of the total agricultural exports during the year 2016-17 with annual earnings of US\$ 5.78 billion ( $₹ 37,870$ crores). Frozen shrimp contributes maximum share of about $66 \%$ by value and $39 \%$ by quantity. The present study has examined the geographical penetration, composition and unit value realisation of frozen shrimp exports from India. It also estimates the competitiveness index, comparative advantage and market diversification of Indian frozen shrimp exports in the world exports market. India's total fishery exports has risen from 0.3 million tons to 0.95 million tons during the period 1995-96 to 2015-16 with a compound growth rate of $6.46 \%$. India has lost its market share in Japan but has gained in South East Asia and European Union market during the period 1995-96 to 2014-15. India's frozen shrimp exports to major export destinations like Japan, USA and EU have been getting diversified over the period.
\end{abstract}

Keywords: Compound growth rate, export competitiveness index, revealed comparative advantage, revealed symmetric comparative advantage, Simpson index of diversity

Seafood contributes $17.07 \%$ of the total agricultural exports of India during the year 2016-17. Under the Special Focus Initiative of the Foreign Trade Policy of the Government of India, the marine sector has been identified as a sunrise sector (http://dgft.gov.in; Gopal et al. 2009). Indian seafood exports achieved an all-time high of 11,34,948 MT and US\$ 5.78 billion (₹ 37, 870.90 crores) in 2016-17 as against 9,45,892 tons and 4.69 billion dollars a year earlier, with the USA and South East Asia continuing to be the leading importers. But the demand from the European Union (EU) grew substantially during the same period. India's positive growth in seafood exports during this period is due to increase in the production of L. Vannamei, diversification of aquaculture species, sustained measures to ensure quality, and infrastructure facilities for production of value-added products (PIB, 2017, MPEDA 2017; Financial Express, 2017).

The exports of frozen shrimp from India has been rising over the past few years, and in 201516 , it contributed almost $66 \%$ of the total marine products exported from the country in value terms. However, in quantitative terms, its contribution was only $39 \%$ indicating high unit value realisation 
of the products. This development in the shrimp farming sector has led not only to growth in shrimp farming but also the discovery of new markets, price discovery, product differentiation, niche markets and challenges of foreign exchange rate fluctuation. In the year 2015-16, USA was leading market for shrimp exporter of India with a market share of $36 \%$ by the quantity and $41 \%$ of the value (MPEDA 2017). Other shrimp exports markets are the European Union, Japan and South East Asia. Nevertheless, the exported seafood commanded premium prices in the market. This paper analyses India's market shares in world exports for fish and fishery products over the period 1995-96 to 2013-14. This paper also examined the competitiveness index and comparative advantage of Indian frozen shrimp exports in the world exports market.

\section{MATERIALS AND METHODS}

\section{Compound Growth rate}

Compound growth of production with respect to time was calculated. In a simple linear regression, by denoting $Y_{t}$ the dependent variable (exports data) at time $t$ and $r$ as the compound growth rate, the model employed for estimating $r$ is derived from eq. (1): (Gujarati. 2003 and, Prajneshu and Chandran, 2005).

$$
Y_{t}=a b^{t} \ldots
$$

The model is linearised using logarithmic transformation, as shown in giving eq. (2):

$$
\operatorname{Ln} Y_{t}=A+B t+\mu
$$

Where,

$$
\begin{aligned}
& Y_{t}=\text { dependent variable } \\
& A=\operatorname{Ln}(a) \ldots \text { intercept } \\
& B=\operatorname{Ln}(b) \text { or } \operatorname{Ln}(1+r) \text { rate of change with change } \\
& \text { in time } \\
& T=\text { period (in years) } \\
& \mu=\text { error term }
\end{aligned}
$$

eq. (2) is then fitted to the data using "method of least squares" and finally, the compound growth rate is estimated by eq. (3)

$$
r=[\exp (B)-1] \times 100
$$

The growth rates for total fish and fishery exports and frozen shrimp regarding quantity for India as well as the entire world were calculated.

\section{Exports Competitiveness Index (XCI)}

Exports competitiveness is the ability of a region to export more in value than it imports. To find the export competitiveness for frozen shrimp from India, changes in world market share were estimated. The long-term comparative advantage of the country can be obtained from the changes in world market shares over time (XCI) (Pasteels, 1998; Rani et al. 2014). If XCI is above one, then it can be said that the country has competitiveness in the exports of that product and vice-versa.

The $\mathrm{XCI}$ is measured as;

Change in world market share $=$

Country's export of product $p$ at time $t \div$ World export of product at time $t$

Country's export of product $p$ at time $t-1$
$\div$ World export of product at time $t-1$

\section{Revealed Comparative Advantage (RCA)}

The product groups of the target country which has an advantage in international exports competitiveness is identified by using The Balassa Index known as 'Revealed Comparative Advantage' (RCA) (Balassa, 1965; Rani et al., 2014). RCA is an important measure of export competitiveness. Comparative advantage can be used as a concept to provide a basic explanation of the pattern of specialisation in production and trade (Anon, 1986). A country is said to have a revealed comparative advantage in a commodity, when RCA value is greater than unity for the given country in the given commodity. Therefore, this study also makes use of RCA to know the exports competitiveness of Indian frozen shrimp in the international market and is represented as follows:

$$
R C A=\frac{\begin{array}{c}
\text { Frozen shrimp export of India } \div \\
\text { Total export of India }
\end{array}}{\begin{array}{c}
\text { World foregn shrimp export } \div \\
\text { World total export }
\end{array}}
$$

However, the problem of asymmetry arises in RCA as it is not comparable on both sides of unity. A country is said not to be specialised in a given sector, if the index ranges from zero to one. While a 
country is said to be specialised, if the value of the index ranges from one to infinity. So, the index is made symmetric, using the methodology suggested by Dalum et al. (1998) and the new index is called 'revealed symmetric comparative advantage' (RSCA).

Mathematically, it can be expressed by Equation:

$$
R S C A=(R C A-1) /(R C A+1)
$$

The new index ranges between -1 and +1 which is free from the problem of skewness. A commodity is said to have a comparative advantage in its exports if the corresponding RSCA value is positive and vice-versa (Shinoj and Mathur, 2008). In this study, RSCA is used to find the comparative advantage of frozen shrimp exports.

\section{Simpson index of diversity (SID)}

Simpson index of diversity (SID) measured the diversification or concentration in exports concerning a specific geographic region in a given period and this was used for the study (Joshi et al. 2003; Shinoj et al. 2009). It ranges from 0 and 1 . If the index tends towards 0 , there exists complete specialisation, and in cases of complete diversification, it tends towards 1. The Simpson Index (SID) is calculated as follows:

$$
S I D=1-\sum_{i=1}^{n} W_{i}^{2}
$$

and

$$
W_{i}=\frac{x_{i}}{\sum_{i=1}^{n} x_{i}}
$$

Where,

$$
\begin{aligned}
& X_{i}=\text { Value of exports/import of } i^{\text {th }} \text { agricultural } \\
& \text { commodity, } \\
& W_{i}=\text { Proportionate value of exports/import of } i^{\text {th }} \\
& \text { agricultural commodity out of total agricultural } \\
& \text { exports/imports. }
\end{aligned}
$$

\section{RESULTS AND DISCUSSION}

Table 1 gives the contribution of fish products and frozen shrimp exports of India to the world markets in quantity and value terms from 1995-96 to 2013-14. World total fishery exports during the year 1995-96 was 22.48 million tons and in value, US \$52,300 million, which increased to 38.41 million tons and US \$139,100 million in the year 2013-14. While
India's total fish exports during the year 1995-96 was 0.3 million tons in quantity, value was US \$ 3,500 million, which rose to 0.95 million tons and US \$ 30,400 million in 2015-16. But India's share of fish and fishery products exports to world exports in quantitative terms increased from $1.32 \%$ to $2.56 \%$ during the period 1995-96 to 2013-14. During 199595 , total frozen shrimp exports of the world was 0.97 million tons in quantity and the US \$8,385 million in value out of which frozen shrimp exports from India was 0.09 million tons valued at US \$ 748 million. Frozen shrimp exports of the world increased to 1.85 million tons and US \$15,205 million during 201314 while India's share rose to 0.37 million tons and US \$3,097 million. India's share of frozen shrimp exports to world exports increased from $9.91 \%$ to $16.26 \%$ during 1995-96 to 2013-14.

Based on the frozen shrimp exports and total fish and fishery exports from India for the period 19952016, the compound growth rate of frozen shrimp exports was $5.84 \%$ while that total fish exports was $6.46 \%$. Also, the compound growth rate of frozen shrimp exports and total fishery exports for the entire world was $4.26 \%$ and $2.99 \%$ respectively. It can also see from the table 1 that the annual growth rate of frozen shrimp and total fish and fish products exports from India has been registering positive growth over the years indicating a healthy trend.

It can also be seen from Table 1 that India registered the highest growth rate during the year 2013-14 of about $31.85 \%$ for frozen shrimp and for total fish exports $28.4 \%$ was achieved during the year 2000-01. While the rest of the world experienced the highest growth rate of frozen shrimp, which was $11.37 \%$ during 2003-04, for fish and fishery exports, it was $8.21 \%$ during $2000-01$.

The overall exports of frozen shrimp from India during 2015-16 was to the tune of 373.87 thousand tons worth the US \$ 3097 million, which increased from 111.87 thousand tons and US \$ 985 million during 2000-01. From Table 2, it is observed that Japan was the leading shrimp importer from India during 2000-01 with a quantity of 45.77 thousand tons worth US \$ 501 million, which is followed by the USA (25 thousand tons worth US \$ 216 million), the European Union (21.74 thousand tons worth US \$ 135 million), South East Asia (6 thousand tons worth US \$ 49 million), China (6 thousand tons 
. Singh et al.

Table 1: Frozen shrimp and Total fish exports from India and world during 1995-14. (Quantity in million tons \& Value in the US \$ million)

\begin{tabular}{|c|c|c|c|c|c|c|c|c|c|c|c|c|}
\hline \multirow{3}{*}{ Item } & \multicolumn{3}{|c|}{ India } & \multicolumn{3}{|c|}{ World exports } & & & Wo & & \multirow{2}{*}{\multicolumn{2}{|c|}{$\begin{array}{l}\text { India Share to } \\
\text { World Markets }\end{array}$}} \\
\hline & \multicolumn{6}{|c|}{ Frozen shrimp } & \multicolumn{4}{|c|}{ Total fish exports } & & \\
\hline & Q & V & $\begin{array}{c}\text { Growth } \\
\text { rate }\end{array}$ & Q & V & $\begin{array}{c}\text { Growth } \\
\text { rate }\end{array}$ & Q & $\begin{array}{c}\text { Growth } \\
\text { rate }\end{array}$ & Q & $\begin{array}{c}\text { Growth } \\
\text { rate }\end{array}$ & $\begin{array}{l}\text { Frozen } \\
\text { shrimp }\end{array}$ & Total \\
\hline $1995-96$ & 0.09 & 7482 & & 0.97 & 8385 & & 0.30 & & 22.48 & & 9.91 & 1.32 \\
\hline $1997-98$ & 0.10 & 8664 & -3.90 & 1.03 & 8258 & 3.77 & 0.39 & 2.01 & 24.17 & 4.35 & 9.87 & 1.60 \\
\hline 1999-00 & 0.11 & 8466 & 7.60 & 1.07 & 7537 & -6.25 & 0.34 & 13.24 & 24.15 & 8.00 & 10.35 & 1.42 \\
\hline 2000-01 & 0.12 & 9850 & 1.45 & 1.14 & 8501 & 6.63 & 0.44 & 28.41 & 26.14 & 8.21 & 9.85 & 1.69 \\
\hline 2003-04 & 0.13 & 8766 & -3.74 & 1.45 & 8325 & 11.37 & 0.41 & -11.83 & 28.17 & 2.35 & 8.94 & 1.46 \\
\hline 2005-06 & 0.15 & 9704 & 5.14 & 1.63 & 8555 & 4.99 & 0.51 & 11.02 & 31.10 & 4.42 & 8.93 & 1.65 \\
\hline 2007-08 & 0.14 & 9806 & -0.85 & 1.67 & 9670 & -1.51 & 0.54 & -11.58 & 31.74 & 1.05 & 8.15 & 1.71 \\
\hline 2008-09 & 0.13 & 8393 & -7.48 & 1.63 & 10016 & -2.56 & 0.60 & 11.29 & 32.31 & 1.83 & 7.74 & 1.87 \\
\hline 2009-10 & 0.13 & 8830 & 3.58 & 1.70 & 9833 & 4.46 & 0.68 & 12.54 & 32.59 & 0.85 & 7.68 & 2.08 \\
\hline 2010-11 & 0.15 & 12618 & 16.02 & 1.87 & 11410 & 9.94 & 0.81 & 19.85 & 34.34 & 5.36 & 8.10 & 2.37 \\
\hline 2011-12 & 0.19 & 17412 & 24.86 & 1.98 & 12393 & 6.07 & 0.86 & 6.02 & 35.36 & 2.99 & 9.54 & 2.44 \\
\hline 2012-13 & 0.23 & 18033 & 20.88 & 1.84 & 12623 & -7.11 & 0.93 & 7.68 & 36.34 & 2.75 & 12.41 & 2.55 \\
\hline 2013-14 & 0.30 & 32109 & 31.85 & 1.85 & 15205 & 0.66 & 0.98 & 5.98 & 38.41 & 5.71 & 16.26 & 2.56 \\
\hline 2014-15 & 0.36 & 37098 & 18.60 & & & & 1.05 & 6.86 & & & & \\
\hline 2015-16 & 0.37 & 30967 & 4.58 & & & & 0.95 & -10.02 & & & & \\
\hline Compo & nd Gro & th rate & 5.84 & & & 4.26 & & 6.46 & & 2.99 & & \\
\hline
\end{tabular}

Source: MPEDA and Fishstat, FAO

Table 2: Country wise frozen shrimp exports from India during 2000-16 (Quantity in thousand tons \& Value in the US \$ million)

\begin{tabular}{ccccccccccccc}
\hline Country & & $\mathbf{2 0 0 0 - 0 1}$ & $\mathbf{2 0 0 2 - 0 3}$ & $\mathbf{2 0 0 4 - 0 5}$ & $\mathbf{2 0 0 6 - 0 7}$ & $\mathbf{2 0 0 8 - 0 9}$ & $\mathbf{2 0 1 0 - 1 1}$ & $\mathbf{2 0 1 1 - 1 2}$ & $\mathbf{2 0 1 2 - 1 3}$ & $\mathbf{2 0 1 3 - 1 4}$ & $\mathbf{2 0 1 4 - 1 5}$ & $\mathbf{2 0 1 5 - 1 6}$ \\
\hline Japan & $\mathrm{Q}$ & 45.77 & 31.41 & 27.83 & 26.42 & 23.24 & 27.82 & 32.22 & 28.65 & 28.72 & 30.43 & 34.20 \\
& $\mathrm{~V}$ & 501 & 260 & 207 & 217 & 187 & 271 & 334 & 261 & 315 & 351 & 316 \\
USA & $\mathrm{Q}$ & 25.01 & 48.58 & 34.02 & 24.70 & 17.50 & 34.24 & 50.57 & 75.42 & 95.93 & 112.70 & 134.14 \\
& $\mathrm{~V}$ & 216 & 394 & 302 & 238 & 152 & 372 & 549 & 663 & 1219 & 1376 & 1254 \\
European & $\mathrm{Q}$ & 21.74 & 31.56 & 44.85 & 56.97 & 61.97 & 57.57 & 55.85 & 63.82 & 73.49 & 81.95 & 81.85 \\
Union & $\mathrm{V}$ & 135 & 154 & 239 & 344 & 347 & 379 & 415 & 430 & 661 & 727 & 605 \\
China & $\mathrm{Q}$ & 6 & 3.16 & 2.84 & 3.28 & 1.78 & 2.41 & 2.43 & 4.43 & 6.19 & 5.30 & 9.54 \\
& $\mathrm{~V}$ & 39 & 12 & 12 & 16 & 10 & 15 & 18 & 33 & 54 & 45 & 67 \\
South East & $\mathrm{Q}$ & 6 & 9.10 & 8.37 & 3.41 & 1.56 & 4.33 & 13.96 & 17.43 & 52.53 & 69.07 & 65.19 \\
Asia & $\mathrm{V}$ & 49 & 68 & 57 & 25 & 11 & 30 & 138 & 135 & 537 & 656 & 487 \\
Middle East & $\mathrm{Q}$ & 4.25 & 5 & 7.06 & 7.37 & 7.21 & 8.58 & 12.90 & 13.63 & 15.16 & 21.64 & 17.48 \\
& $\mathrm{~V}$ & 21 & 22 & 35 & 46 & 50 & 66 & 107 & 101 & 139 & 199 & 139 \\
Others & $\mathrm{Q}$ & 3.09 & 6.02 & 13.11 & 15.24 & 12.79 & 16.52 & 21.21 & 25.25 & 29.42 & 36.42 & 31.46 \\
& $\mathrm{~V}$ & 24 & 42 & 87 & 111 & 82 & 129 & 180 & 180 & 286 & 357 & 229 \\
Total & $\mathrm{Q}$ & 111.87 & 134.82 & 138.08 & 137.40 & 126.04 & 151.46 & 189.13 & 228.62 & 301.44 & 357.51 & 373.87 \\
& $\mathrm{~V}$ & 985 & 953 & 938 & 998 & 839 & 1262 & 1741 & 1803 & 3211 & 3710 & 3097 \\
\hline
\end{tabular}

Source: MPEDA 
worth US \$ 39 million), Middle East (4.25 thousand tons worth US \$ 21million) and others markets (3.09 thousand tons worth US \$ 24 million).

India has lost its market share to Japan while India gained other markets such as USA, EU, South East Asia, China, Middle East. Also, the USA becomes the India's single frozen shrimp exports market with a share of $36 \%$ by quantity and $41 \%$ by value in the year 2015-16. But India also experienced a decline in market share of the USA during the period 2004-09. During 2006-07, value of shrimp exports from the USA dropped by $23 \%$. After the anti-dumping duties came into effect, the number of Indian exporters to the United States declined in a significant way from 280 in 2005 to just 68 in 2009 (Ancy and Raju, 2014). Since 2009-10, the market share of India started improving in the USA and thus has emerged as the largest shrimp exporter. This might be due to the disease (Early Mortality Syndrome) that hit Thailand's shrimp production; Indian shrimp culture diversification from lowvolume, high-value Penaeus monodon (black tiger) to high-volume Penaeus vannamei (India Business, 2016).

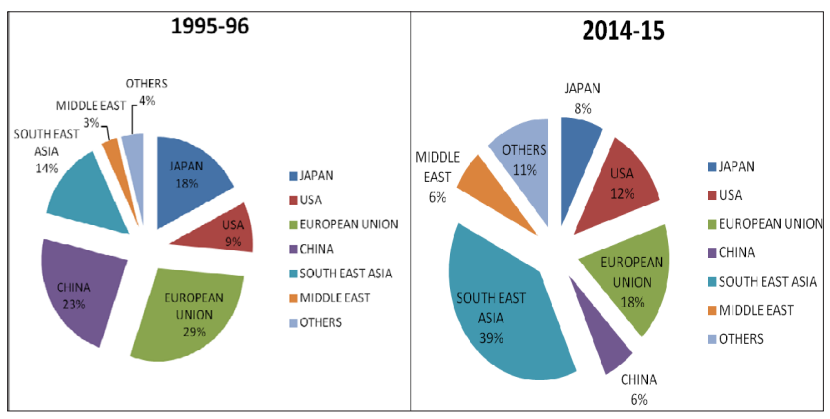

Fig. 1: Quantum Change in Market Share (1995-96/2014-15)

Fig. 1 shows the change in quantity of fish and fishery exports from India among markets during 1995-96 to 2014-15. During 1995-96, European Union contributed the highest market share, about $29 \%$, which is followed by China (23\%), Japan (18\%), South East Asia (14\%), USA (9\%), Middle East (3\%) and other markets (4\%). South East Asia became the leading contributor and its market share was about $39 \%$ during the year 2014-15. India lost its market share in the European Union, China, and Japan, which reduced to $18 \%, 6 \%$ and $8 \%$ respectively. While the USA and the Middle East increased their market share to $12 \%$ and $6 \%$ respectively.

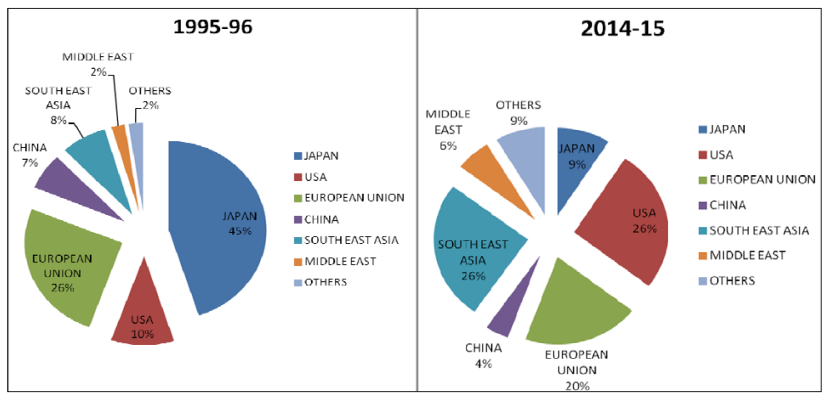

Fig. 2: Change in Market share in value terms (1995-96/2014-15)

Fig. 2 represented the change in market shares in fish and fishery exports in value terms from India. Japan was the primary market for India's shrimp exports market in value terms yielding a market share of about $45 \%$ during 1995-96. But it reduced to only $9 \%$ during 2014-15. This reduction may be due to the competition from Thailand, Vietnam, etc. Japan banned exports of shrimp from India because of the detection of the presence of antibiotic in exports consignments from India (The Nation, 2012). The USA, South East Asia and the European Union were the leading markets for Indian seafood during $2014-15$ by contributing about $26 \%, 26 \%$ and $20 \%$ respectively. The contribution of other smaller market including Middle east and China was 19\%. Even though the bulk of exports (39\%) was directed towards South East Asia, they were mostly lowvalue products, so its share was only $26 \%$ by value. The fish and fishery exports basket consisted mainly of frozen finfish, frozen squid, dried and live items, etc. Owing to the higher purchasing power of the consumers in the developed economies countries like the European Union, the USA and Japan, most of the high-value products are exported to these countries (Shinoj et al. 2009). The USA contributed $26 \%$ by value, though its share was only $12 \%$ by quantity.

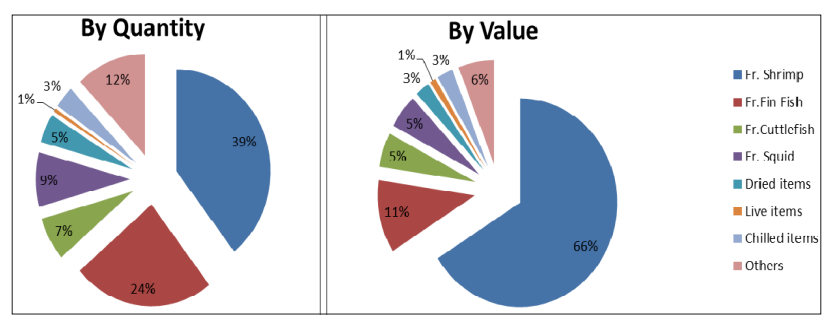

Fig. 3: Item-wise market share of India fish and fishery exports during 2015-16

Fig. 3 shows the item-wise market share of India fish and fishery product exports during 2015-16 


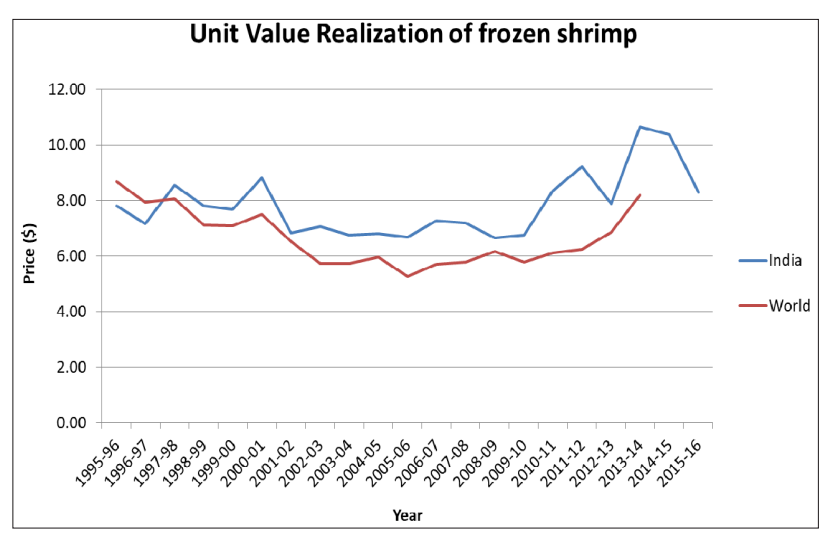

(A)

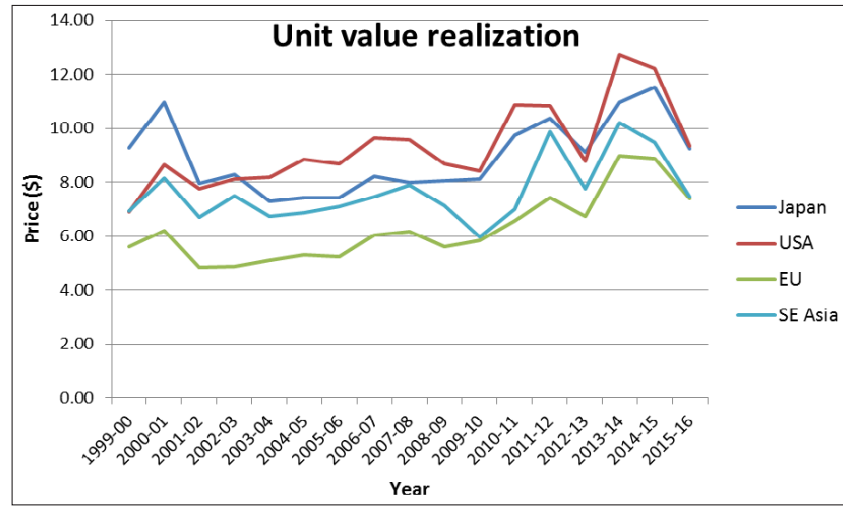

(B)

Fig. 4: Unit value realisations for frozen shrimp

by quantity as well as value terms. In both value and quantitative terms, frozen shrimp contributed the maximum share, i.e. about $66 \%$ and $39 \%$ respectively. The item such as frozen finfish, frozen cuttlefish, frozen squid and dried fish followed frozen shrimp in quantity with a market share of 24 , 7,9 and $5 \%$ respectively. The contribution of frozen finfish in terms of quantity and value was $24 \%$ and $11 \%$ respectively. This difference is due to the low price of fish in comparison to shrimps.

\section{Unit Value Realization}

The Fig. 4(A) is a graphical representation of unit value realisation of frozen shrimp from India and world during 1995-96 to 2015-16. The average unit price for frozen shrimp was slightly higher in India than the world price. India maintained higher value per unit of export over the world exports of the product in most of the years, which showed creditable performance of India in terms of unit value realisation. India attained higher average exports price for frozen shrimp during the year $2013-14$, about US $\$ 10.65 / \mathrm{kg}$, and the lowest was US $\$ 6.68 / \mathrm{kg}$ in $2005-06$. The fluctuation in terms of unit value declined during the period 2002-10.

Fig. 4(B) gives the unit price realisation for frozen shrimp exports to markets viz. Japan, USA, EU and South East Asia from India. It can be seen that unit price increased over time. It was also found that average unit price for frozen shrimp in USA market was higher than Japan, South East Asia and EU markets. EU market recorded the lowest unit price than other markets. These may be due to the reason that the USA and Japan were importing high-value species as well as higher grade (count) while South East Asia and EU were importing lower value species and smaller counts.

\section{Exports Competitiveness Index (XCI)}

Fig. 5 shows the exports competitive index for frozen shrimp exports from India. The XCI of frozen shrimp from India can be seen to be fluctuating in nature, but it lies around 1 which indicated that India has an export competitiveness in frozen shrimp exports over the period. The XCI fell below 1 during the year 1997-98, 1998-99, 2000-01, 200304 and 2006-07 but it was very close to 1 . The XCI registered a value of 1.3 which was the highest during 2012-13 and 2013-14.

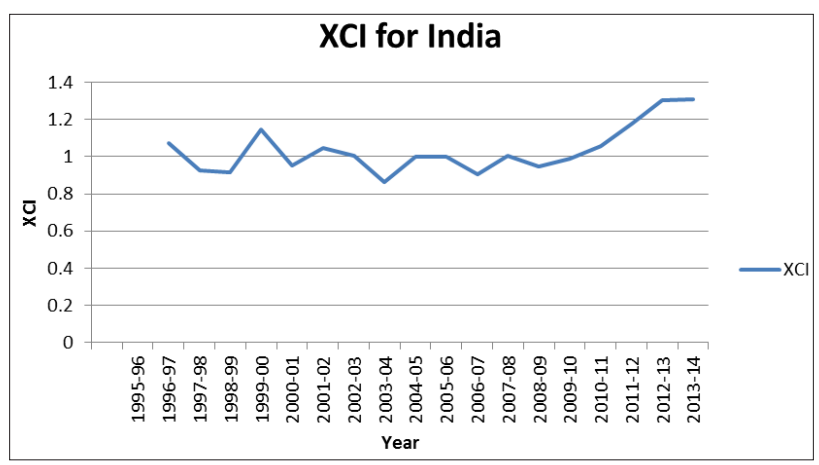

Fig. 5: Exports competitiveness index (1995-2014)

\section{Revealed Symmetric Comparative Advantage (RSCA)}

Fig. 6 shows the revealed symmetric comparative advantage of frozen shrimp exports from India during 1995-2014. It registered a positive trend that is more than zero which indicated that India has the comparative advantage of the product (frozen 
shrimp). India RSCA was 0.76 during 1995-96 which was the highest value to date, and reduced to 0.72 in 1997-98. Again RSCA improved to 0.75 during 1999-2000, and it has gradually decreased to its lowest which was 0.54 during 2010-11. Though it declined, India still attained its comparative advantage in international markets because RSCA never went below zero. The RSCA improved again to 0.73 in 2013-14. RSCA values for India showed a fluctuating trend (Fig. 6), this can be due to high dependency on wild capture or a relative shift of exports towards low-value alternatives like finfish and diversification of the exports basket.

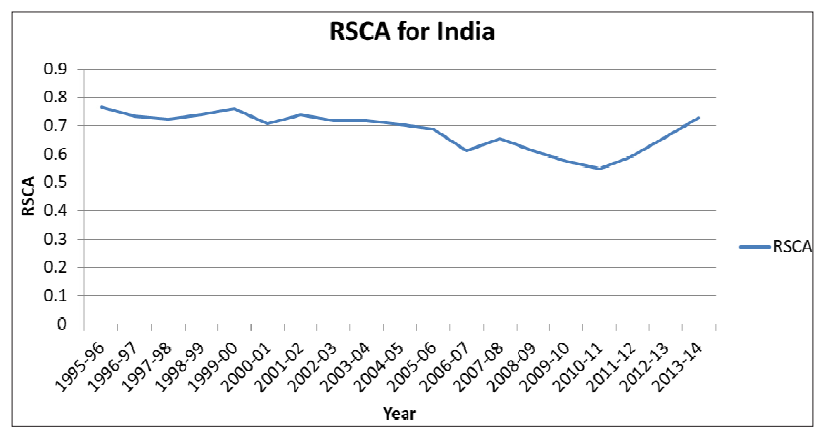

Fig. 6: Revealed Comparative Advantage for India 1995-2014

\section{Simpson Index of Diversity of frozen shrimp}

Fig. 7 shows the Simpson index of diversity which quantified the extent of diversification of frozen shrimp exports during 1999 to 2015-16.

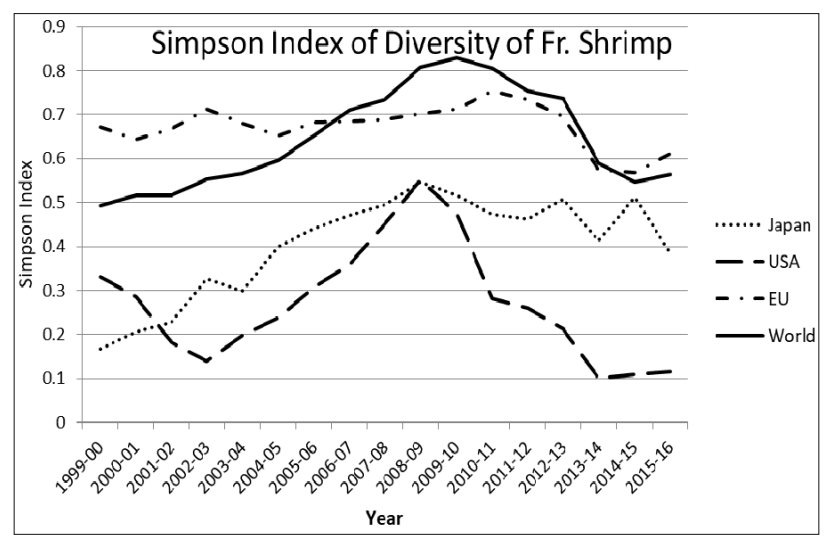

Fig. 7: Simpson Index of Diversity of frozen shrimp

It can be seen that the commodity basket of India's fish exports to major exports destinations is getting diversified over the periods. The Simpson index of diversity of exports to the world increased from 0.49 to 0.82 during the year 1999 to 2009-10, and then, decreased to 0.56 in the year 2015-16. The frozen shrimp exports to largest destinations like Japan, USA and EU, also got diversified but frozen shrimp exports to the EU being the most diverse.

\section{CONCLUSION}

India's seafood (Fish and Fishery products) exports have registered a positive growth over the years, indicating a healthy trend with a growth rate of $6.46 \%$ during the period 1995-96 to 2015-16. South East Asia contributed 39\% of the market share of seafood exports in quantity terms during the year 2014-15, but in value terms, the USA share was about $26 \%$. Among the various commodities of seafood exported from the country, frozen shrimp holds the prime status. Frozen shrimp contributes about $66 \%$ by value to that of total fish and fishery exports, the primary destinations being the USA and Japan. It is found that RSCA values for India showed a fluctuating trend this can be due to shifts in exports towards low value alternatives like finfish and diversification of the exports basket. It can also be seen that, India's seafood exports commodity basket diversified and is showing a decline in low-value exports routed to South East Asian and Middle East countries at the expense of premium priced shrimp which used to find markets in Japan (Shinoj et al., 2009). However, USA continues to be a preferred destination for shrimp exports.

\section{ACKNOWLEDGEMENTS}

The authors are grateful to Director/ Vice Chancellor, ICAR-Central Institute of Fisheries Education, Mumbai for constant encouragement and support during this work. Thanks are also to Marine Products Exports Development Authority (MPEDA), Kochi, India for data.

\section{REFERENCES}

Ancy, V.P. and Raju, K.V. 2014. Indian Shrimp Exports and US Anti-Dumping Duty: Issues and Challenges. Asian Review of Social Sciences, 3(2).

Anon. International Comparative Advantage in Manufacturing: Changing Profiles of Resources and Trade. 1986; p 226, United Nations Industrial Development Organization (UNIDO), Vienna, ISBN: 9211062101.

Balassa, B. 1965. Trade liberalisation and revealed comparative advantage. Manchester School of Econ. and Social Studies, 33: $99-123$.

Bhattacharyya, B. 2004. State of the Indian Farmer A Millennium Stuty. Agric Export, 18. Academic Foundation, New Delhi. 
Dalum, B.K., Laursen, K. and Villumsen, G. 1998. Structural change in OECD exports specialisation patterns: Despecialisation and 'stickiness'. Intl. Rev. of Appl. Econ., 12: 447- 467.

Financial express. India's seafood exports at all-time high, revenue soars to $\$ 5.78$ bn. 2017 June 8; Available from: http://www.financialexpress.com/market/commodities/ indias-seafood-exports-at-all-time-high-revenue-soarsto-5-78-bn/706814/

Gopal, N., Jeyanthi, P., Geethalakshmi, V. and Unnithan, G.R. 2009. Indian Finfish Exports - An Analysis of Exports Performance and Revealed Comparative Advantage. Agric. Econ. Res. Rev., 22: 291-297.

Gujarati, D.N. 2003. Basic Econometrics. Fourth edition. United States Military Academy. West Point McGraw-Hill Higher Education New York, NY, 10020. International edition.

Joshi, P.K., Gulati, A., Birthal, P.S. and Tewari, L. 2003. Agriculture Diversification in South Asia: Patterns, Determinants and Policy Implications. MSSD Discussion Paper No. 57, Intl. Food Policy Res. Inst. Washington, D.C., U.S.A.

MPEDA. Annual Report Compliation Unit, Marine Products Exports Development Authority, Panampilly Nagar, Kochi, Accessed 2 November, 2017.
Pasteels, J.M. 1998. Foreign Trade Statistics: A guide for their use in market research. International Trade Centre UNCTAD/ WTO Paper.

Prajneshu and Chandran, K.P. 2005. Computation of compound growth rates in agriculture: Revisited. Agric. Econ. Res. Rev., 18: 317-324.

Press Information Bureau (PIB). India's Seafood Exports at all-time High in 2016-17: MPEDA. Government of India, Ministry of Commerce \& Industry 07-June-2017. Available from: http://pib.nic.in/newsite/ PrintRelease.aspx?relid=164454

Rani Prathvi, Sheela Immanuel and Nalini Ranjan Kumar. 2014. Ornamental Fish Exports from India: Performance, Competitiveness and Determinants. Intl. J. of Fisheries and Aquatic Studies, 1(4): 85-92.

Shinoj, P. and Mathur, V.C. 2008. Comparative Advantage of India in Agricultural Exports vis-à-vis Asia: A Post Reforms Analysis. Agric. Econ. Res. Rev., 21(1): 60-66.

Shinoj, P., Ganesh Kumar, B., Joshi, P.K. and Datta, K.K. 2009. Exports of India's Fish and Fishery Products: Analysing the Changing Pattern/Composition and Underlying Causes. Ind. J. Agric. Econ., 64(4): 541-556.

The Nation. Japan's ban of Indian shrimp a boom to Thai exports. Yupin Pongthong. 24 $4^{\text {th }}$ Oct. 2012. Retrieved from http://www.pressreader.com/thailand/the-nati on/20121024/281560878040407. 